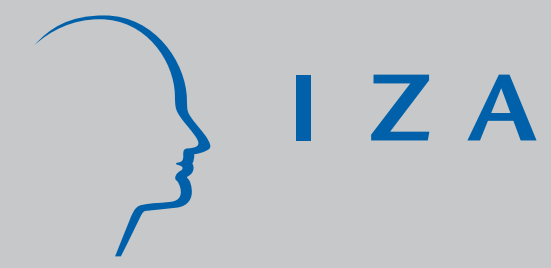

IZA DP No. 7435

Management Compensation and the Economic Crisis: Longitudinal Evidence from the German Chemical Sector

Christian Grund

Tanja Walter

May 2013 


\title{
Management Compensation and the Economic Crisis: Longitudinal Evidence from the German Chemical Sector
}

\author{
Christian Grund \\ RWTH Aachen University \\ and IZA
}

Tanja Walter

RWTH Aachen University

Discussion Paper No. 7435

May 2013

IZA

P.O. Box 7240

53072 Bonn

Germany

Phone: +49-228-3894-0

Fax: +49-228-3894-180

E-mail: iza@iza.org

Any opinions expressed here are those of the author(s) and not those of IZA. Research published in this series may include views on policy, but the institute itself takes no institutional policy positions. The IZA research network is committed to the IZA Guiding Principles of Research Integrity.

The Institute for the Study of Labor (IZA) in Bonn is a local and virtual international research center and a place of communication between science, politics and business. IZA is an independent nonprofit organization supported by Deutsche Post Foundation. The center is associated with the University of Bonn and offers a stimulating research environment through its international network, workshops and conferences, data service, project support, research visits and doctoral program. IZA engages in (i) original and internationally competitive research in all fields of labor economics, (ii) development of policy concepts, and (iii) dissemination of research results and concepts to the interested public.

IZA Discussion Papers often represent preliminary work and are circulated to encourage discussion. Citation of such a paper should account for its provisional character. A revised version may be available directly from the author. 


\section{ABSTRACT \\ Management Compensation and the Economic Crisis: Longitudinal Evidence from the German Chemical Sector}

Making use of unique balanced panel data for the German chemical sector from the years 2008 to 2011, we explore the extent to which managers' compensation was affected by the economic crisis and the extent to which it increased afterwards. Carrying out longitudinal analyses, we find that, on average, bonus payments (in contrast to fixed salaries) decrease considerably during the crisis. The economic upturn in 2011 then leads to an average increase in variable payments and total compensation to even above the pre-crisis level. Changes in bonus payments are negatively correlated over time. We find considerable differences across employees with respect to changes in bonus payments. Fixed salary changes are much more homogeneous over the period of crisis. We explore determinants of compensation changes and find that changes in compensation have a strong relationship with employees' age, firm size and hierarchical level. Our findings hint at the relevance of an incentive perspective. We also examine that certain parts of managers seem to have more power to influence their compensation than others. Inequality in managers' compensation decreased during the crisis.

JEL Classification: M52, M12, J33

Keywords: bonus payments, economic crisis, fixed salaries, management compensation

Corresponding author:

Christian Grund

RWTH Aachen University

Templergraben 64

52056 Aachen

Germany

E-mail: christian.grund@rwth-aachen.de 


\section{Introduction}

In 2009, most countries were hit by the worst economic crisis since the Great Depression of the 1930s, with their GDPs slumping and unemployment increasing. Except for these and some other macroeconomic factors, however, there is not much micro evidence for the issue, of how individuals in ongoing employment relationships were affected by the crisis. A usual argument is that decreasing productivity might cause a downward push on wages (O`Farrell, 2010).

The objective of this contribution is to shed light on the development of management compensation during the crisis. We focus on a broad group of highly qualified professionals and managers in the German chemical sector. Making use of a unique balanced panel data set from the years 2008 to 2011, we examine the incidence and determinants of compensation reductions during the crisis and subsequent increases in the economic recovery of the sector. The determination of managers` bonus payments and, to some extent, also of increases in fixed salaries is usually attached to performance indicators. Those indicators can be based on individual, group and/or firm levels, and generally refer to the past. Therefore, wage consequences of the crises are expected to be revealed in 2009 and 2010, whereas 2011 may reflect a year with particular increases in managers' compensation. We explore the heterogeneity of management compensation at certain points of time and the development of heterogeneity over time.

This analysis is important for at least two reasons: First, there is hardly any information available about, how the costs of the economic crisis are distributed among employees and how employees` income is affected. Compensation adjustments in times of crisis may lead to earning losses among employees if real compensation has not regained its pre-crisis level. Second, to the best of our knowledge, there has been no previous study that has focused on the individual and firm-specific determinants of compensation changes during and after the crisis. Changes in management compensation may be related to employees' and firms' characteristics. Certain groups of employees may suffer or benefit more than others in terms of compensation reductions during the crisis and with regard to subsequent increases. From an incentive perspective, it can be expected that those who benefit most in good times will suffer most in a crisis, if compensation is attached to a certain performance measure. However, certain groups of employees may have the power to enforce benefits in good times and also protect themselves from cuts in bad times. It is an empirical question, as to whether the incentive perspec- 
tive or the power perspective plays a dominant role in terms of compensation changes during a crisis.

Our paper is related to two strands in the executive compensation literature: First, there is a growing literature on top management compensation in general and its development during the crisis. Second, our paper relates to the literature that studies the determinants of managers` compensation with a focus on fixed salaries and bonus payments.

In the aftermath of the economic crisis, a contentious debate on management compensation has arisen. Several studies have paid attention to the variable payments of top managers during the economic crunch in the financial service sector and focus on pay-for-performance sensitivities (see, e.g., Erkens et al. (2009), Nastansky/Lanz (2010), Fahlenbrach/Stulz (2011), Gregg et al. (2012)). There is, however hardly any evidence for Germany. One exception is that of Fabbri and Marin (2012), who investigate the extent of German CEO remuneration during the recent financial crisis. They make use of an unbalanced panel data set of the 500 largest firms in Germany in the period between 1977 and 2009 and explore disciplining effects of the great recession of 2009 on total CEO payments in Germany. Few studies have focused on lower or middle management. One study that extends the case of top management compensation in Germany is that of Kampkötter and Sliwka (2011), who focus on the impact of the 2008-2009 crisis on middle management bonus payments in the financial service sector. The authors point out inferior bonus decreases than performance declines in 2009. Managers at high hierarchical levels suffer most in terms of reduced bonus payments. It should be noted that none of these studies take the economic recovery into account.

Past research has predominantly focused on the determinants of management compensation with a focus on firm performance and firm size (Finkelstein and Hambrick (1989), Jensen and Murphy (1990), Brenner and Schwalbach (2003)). Few studies focus on the determinants of bonus payments for low and middle management employees (see, e.g., Ortin-Angel and Salas-Fumas (1998), Nash (2003), Grund and Kräkel (2012)). One main result is that bonus relevance is attached to characteristics such as the hierarchical level, functional area, firm size and tenure. Complementary to previous findings, we refer to certain groups of managers by taking some determinants of compensation changes into account. We are able to distinguish between total, fixed and variable payments for employees below the top management level.

Results on compensation changes also contribute to the literature on wage rigidity. Several studies have identified the fact that firms abstain from cutting nominal wages (Baker et al. 
(1994), Card and Hyslop (1997), Bewley, (1999)). Few studies have focused on the rigidity of real wages (Bauer et al. (2003), Dohmen (2004), Babecky et al. (2010)). In this contribution, we investigate changes in real total compensation components between 2008 and 2011.

Our paper contributes to the existing literature mentioned above as follows: Using balanced panel data for the period 2008-2011, we address the issue of the extent to which management compensation has developed during and subsequent to the economic crisis. We are able to analyze the impact of one of the world's worst economic crises on total, fixed and variable payments of managers in the German chemical sector. We examine how the brunt of the crisis is spread across the workforce. We also complement the existing literature on wage rigidity, since we can analyze real wage adjustments during the economic recession. We adhere to the individual perspective and do not take firm performance considerations into account. Our paper leans towards the question of whether differences in compensation changes can be explained by certain firm and individual characteristics. To the best of our knowledge, there has been no previous study that has focused on the determinants of compensation changes during and after the economic crisis. Up to now, there has also been scant evidence for (middle) management compensation that exceeds the case of top managers in general.

The remainder of the paper is structured as follows: We begin by briefly describing the German chemical sector and its economic development during and after the economic crisis. In section 3, we provide considerations for the development of managers`compensation during the crisis in general by also taking determinants of compensation changes into account. Subsequently, we encapsulate our data and our variables in section 4. The empirical findings are presented in section 5. Section 6 sums up and concludes.

\section{The German chemical sector during and after the crisis}

In 2009, Germany was hit hard by the economic crisis - observable, for instance, in a nearly 5 percent decrease in GDP (OECD, 2010). The German economy recovered astonishingly quickly. One reason may have been the terminated slag in output to the exporting industry. Brenke et al. (2011) point out that spillover effects to other sectors than the export oriented ones were limited. Responsible for some 15 percent of total German exports, the German chemical sector is the largest chemical exporter worldwide (VCI, 2012). The chemical industry is dominated by large firms. The ten biggest firms of the sector employ more than half a million people. The mentioned economic disturbances were also having a considerably nega- 
tive impact on the German chemical industry. The association of the German chemical sector, VCI (Verband der Chemischen Industrie), reports an annual output decline of 10 percent in 2009, compared to declines of 4.9 and 4.2 percent for the chemical sector in Europe and in the United States, respectively. Sales even fell by 15 percent during the crisis (Merck Annual Report, 2009). Nonetheless, the industry rode out the crisis fast. In 2011, the German chemical industry exceeded the pre-crisis level of the year 2008 in terms of production and sales. This went hand in hand with increases in the German GDP of more than 3\% in 2010 and in 2011, compared to previous years` levels.

\section{Theoretical considerations and hypotheses}

We first provide some considerations for the development of managers' compensation during the crisis in general. Subsequently, we refer to certain groups of managers in particular by taking some determinants of compensation changes into account. Wherever applicable, we distinguish between the development of fixed salaries and bonus payments.

Traditional neoclassical economics state that employees are supposed to be paid according to the value of the marginal product, so that wage reductions (or layoffs) occur in times of a recession. However, there are reasons for wage rigidities in the sense that firms abstain from reductions of (fixed) salaries in economically bad times. Lindbeck \& Snower (1989) offer insider-outsider theory as an explanation. Labour turnover costs (such as severance pay, training costs, hiring and firing costs) give insiders some kind of market power to protect themselves from wage reductions. Stiglitz (1986) discusses how firms may abstain from wage reductions because implicit contracts may be implemented as insurance devices for risk-averse employees, or because of a positive relationship between wage increases and employees` productivity in the sense of efficiency theory. Empirical work, both in the field and in the lab, suggests that social preferences and gift exchange considerations are also important explanations (e.g. Bewley 1999, Fehr \& Falk 1999). We therefore presume that fixed salaries are relatively little affected during a crisis which has been resolved in a few years.

This issue is considerably different for bonus payments. A fundamental function of implementing bonus payments within a firm's compensation policy is to induce incentives and to motivate employees. This argument was already mentioned by Berle \& Means (1932) and was formalized in moral hazard versions of principal agent theory (e.g. Ross 1973, Jensen \& 
Meckling 1976, Arrow 1985). Some kind of performance related remuneration is then implemented to align managers' interests with those of the shareholders. An accompanying advantage is that wage costs are then attached to firm success, which avoids liquidity problems in economically bad times. Managers may differ in their pay-for-performance sensitivity. It directly follows that those managers who suffer most in a crisis have the highest increases in the upturn. From this incentive perspective, we can therefore formulate

\section{Hypothesis 1:}

1a) Bonus payments decline in times of crisis and increase in times of economic recovery.

1b) There is a negative serial correlation of increases in bonus payments during a crisis and in the subsequent upturn.

We have to note, however, that we only address middle managers and not the top management of firms, which may lead to a reduced effect. Managers at lower levels of the hierarchy have less scope to affect the performance of the whole firm. Therefore, bonus contracts should be attached more to individual or group performance indicators than to firm performance in order to generate sensible incentives. Large bonus payments in bad economic times would contradict the goal of firm performance dependent wage costs, as stated above.

Previous theoretical and empirical work shows that the degree of pay-for-performance sensitivity is supposed to be positively relative to the hierarchical level. Since efforts on high hierarchical levels are presumed to be more difficult to monitor as well as tasks are often less programmable, monetary incentives should become more important at the upper level (Brenner \& Schwalenbach, 2003). Kräkel \& Schöttner (2012) argue that bonus payments and internal career opportunities may be complements in incentive provision. Grund \& Kräkel (2012) confirm that bonus relevance increases with the level of hierarchy within the German chemical sector. These considerations lead to our

Hypothesis 2: Decreases in bonus payments during the crisis and increases in the upturn are particularly relevant for managers at higher levels of the hierarchy.

However, management compensation itself can also be seen as a part of an agency problem. According to the manager power approach (Bebchuk \& Fried 2003), managers have some degree of power to influence their own remuneration. The greater the managers substantial influence, the greater their ability to extract economic rents in the form of management com- 
pensation that is poorly correlated to performance indicators. Then, some groups of managers, probably those on higher levels of the hierarchy, may have the power to enforce benefits in good times and also protect themselves from cuts in bad times. The relationship presumed in Hypothesis 2 may be less relevant if this power approach is important. It is an empirical question as to whether the incentive or a power perspective plays a dominate role in terms of compensation changes. The power perspective is supposed to be relevant for both bonus payments and fixed salaries. Since the incentive perspective is applied only for bonus payments, we presume that managers at higher levels of a firm's hierarchy benefit from larger increases in fixed salaries during the observation period 2008 to 2011.

A high degree of bonus relevance is hardly conceivable without a formal bonus system that is based on a performance-appraisal system. The implementation and existence of such a system lead to monitoring costs. Monitoring is supposed to be more necessary in larger firms with more anonymous employment relationships. The compensation contract then helps to avoid monitoring costs by establishing a high pay-for-performance sensitivity. Besides, rather larger firms may make use of formal bonus systems, because the fixed costs of implementing a certain system can be "distributed" among a larger number of employees. In contrast, fixed costs may be too large for implementation in small firms. Therefore, bonus relevance is supposed to be higher in large firms, which directly leads to

Hypothesis 3: Decreases in bonus payments during the crisis and increases in the upturn are particularly relevant for managers in large firms.

Further important determinants of the development of manager compensation are independent of the firms' economic situation. Concave wage-age profiles or wage-tenure profiles over time are suggested by human capital theory (Becker 1962, Mincer 1974) and are empirically well established. We therefore expect lower increases in compensation for older persons and those with many years of firm tenure. The relevance of the manager power approach limits this relationship, if older employees (employees with many years of tenure) can accumulate a high degree of power to protect themselves from compensation reduction in times of crisis. It is questionable, however, whether there is any considerable relevance apart from power differences between hierarchical levels.

Long-term employment relationships are predominant in the German chemical sector. However, some employees do switch from one firm to another every year. Since we are not aware 
of fundamental cases of dismissals even on account of the crisis, we can assume employeeinitiated job changes in the majority of cases. Managers will change their job if they are financially better off in the new firm, so we expect particular increases in fixed salaries subsequent to job changes. In contrast, bonus payments are usually attached to some measures of past performance. In the short run, reductions in bonus payments relative to stayers may occur.

\section{Data and Variables}

We make use of a unique longitudinal data set of highly qualified professionals and executives in the German chemical industry. We have detailed information of their annual compensation (e.g. fixed salary and bonus payments) within a four-year period from 2008 to 2011 in addition to information about demographics and their jobs. We conduct a corresponding yearly remuneration survey in cooperation with the German association of executive staff in the chemical industry (Verband angestellter Akademiker und leitender Angestellter der Chemischen Industrie e.V. (VAA)). According to the Association, our sample is representative of the appropriate employees in the German chemical industry. For more detailed information on the data, see Grund \& Kräkel (2012).

Our balanced panel comprises the first four waves of this survey from 2009 to 2012. Since salary data are collected retrospectively, our data cover the period from 2008 to 2011. More than 90 percent of the employees are eligible for bonus payments. This share does not change over the covered period. Concentrating on bonus payments, we restrict our sample to fulltime employees with some kind of bonus contract.

In the questionnaire, managers are asked to match themselves to one of four management levels, whereby level 1 represents the top-management level. Excluding data on the top management level 1 ( 2 percent of individuals), our sample is restricted to the low and middle chemical management of levels 4 to 2 . Thereby, category 4 represents the lowest level of highly qualified employees with some management responsibilities. Level 2 presents senior management.

We deflate total compensation, fixed salaries and bonus payments with the consumer price index of the year 2008. Prices have increased during the observation period by $0.4 \%$ (2009), $1.1 \%$ (2010) and $2.3 \%$ (2011), respectively. 
Based on our restrictions, the sample finally comprises 5,464 observations over the four-year period. We have a balanced panel with 1,366 managers each year. Table 1 provides an overview of the descriptive statistics.

\section{Table 1 about here}

The main part (81 percent) of management compensation is assigned to fixed salaries and 15 percent account for bonus payments, in general. We also investigate other components of compensation, such as stocks, stock options or premiums for inventions, which in sum account for 4 percent of total compensation. The average bonus of those who are eligible for bonus payments is about $€ 19,000$. The annual fixed compensation amounts to almost $€$ 95,000 on average. The average share of bonus payments in total compensation varies somewhat during the crisis from 0.16 in the year 2008 to 0.13 in 2010, and again goes up to 0.17 in 2011. In line with previous findings (see e.g. Kampkötter and Sliwka 2011, Grund and Kräkel 2012), the share of bonus payments is higher for large firms` managers and managers in high hierarchical positions.

In this contribution, we present (i) the structure of absolute compensation and its components over time, (ii) relative changes from year to year, and (iii) a four-year development of compensation based on the initial year 2008 of our investigation. 


\section{Results}

\subsection{Development of compensation}

We begin with a description of the structure of manager compensation in the German chemical sector during the crisis. Figure 1 shows the $10^{\text {th }}$ and $90^{\text {th }}$ as well as $25^{\text {th }}$ and $75^{\text {th }}$ percentiles next to medians for each year from 2008 to 2011.

Average fixed salaries vary slightly from 2008 to 2011 between values of $€ 90,000$ and $€$ 95,000 . Compared to the small extent of variation in fixed salaries over time, bonus payments are much more volatile over the four-year period. Bonus payments decrease considerably during the crisis. The median of bonus payments goes down from about $€ 17,000$ in 2008 to $€$ 14,000 in 2010. With an average bonus of $€ 20,000$, variable payments in 2011 exceed the pre-crisis level of 2008. Thus, the economic upturn leads to an average increase of bonus payments and total compensation. In 2011, the median of total compensation is about $€$ 122,000 . Note that we use real values of compensation.

Figure 1 about here

In the following, we concentrate on year to year compensation changes. Relative changes are computed by the amount of bonus, fixed and total payments compared to the previous year`s levels. Focusing on changes in bonus payments, we can only use observations of individuals with information from two consecutive years. It should be noted that our sample counts 166 observations with zero bonus payments for the covered period. Because relative bonus changes cannot be computed if there was no bonus in the previous year, these observations are excluded for the corresponding analyses. The share of managers with a zero bonus considerably differs across years (see Figure A in the appendix). Before the economic crisis, 2.5 percent of the employees with some kind of bonus contract got a zero bonus payment. In 2009, this percentage doubles to a rate of almost 5 percent, before it has been reduced by more than half to 1.5 percent in the year 2011. This general pattern holds for subgroups of individuals with respect to hierarchical levels and functional areas. We can observe an overall proportional increase of zero bonus payments for all hierarchical levels and functional areas in 2009. In particular, management level 2 was remarkably hit by a rise in the average rate from 3.8 in 2008 
to 8.0 percent in 2009. It is also remarkable that almost all managers in large firms with more than 10,000 employees report positive bonus payments in all years.

The median of relative bonus changes differs considerably across the years from -0.13 in 2009 to -0.07 in 2010 and +0.46 in 2011 . In contrast we observe hardly any variations in median fixed salaries over time (see Figure 2). The median of relative fixed salary changes decreases from 0.03 in 2009 to 0.02 in 2010 and 0.01 in 2011. These differences in real increases can be explained by differences in inflation. Nominal increases are rather stable at about 0.03. Hence, positive changes in total compensation from 2010 to 2011 can largely be assigned to increases in variable payments.

Figure 2 about here

There are moderate differences of changes in fixed salaries across individuals within each year and much more pronounced differences with respect to changes in bonus payments. Examinations of year-to-year changes in bonus payments show that the share of managers with positive changes rises from 0.34 in 2009 to 0.77 in 2011 . Almost three out of four individuals with bonus reductions from 2009 to 2010 report positive bonus changes in 2011. This is true for about 50 percent of the employees. Interestingly, we can observe a kind of regression to the mean effect in the sense that, in general, the proportion of increasing bonus payments is higher for the group of managers who suffered the year before than that of managers who gained before. Pairwise correlation analysis hints at a negative serial correlation of changes in bonus payments over time $\left(\mathrm{r}_{08 / 09 \_09 / 10}=-0.0776, \mathrm{p}<0.001 ; \mathrm{r}_{09 / 10 \_10 / 11}=-0.1766, \mathrm{p}<0.001\right)$. Individuals who suffer during the crisis tend to benefit more in the upturn. These results suggest an incentive rather than a power perspective in terms of bonus changes during and subsequent to the economic crisis.

In a next step, we study the development over the whole observation period from 2008 to 2011. We compute the relative difference of compensation (components) of individuals based on the initial year of our analysis $(2008=100)$. Relative compensation changes are then computed by the amount of bonus, fixed salary and total compensation for the years 2009, 2010 and 2011, compared to the pre-crisis year level of 2008. 
Figure 3 shows the development of median annual compensation components relative to the year 2008. Findings confirm year-to-year changes. On average, managers had to face huge bonus cuts during the crisis. In 2010, employees received, on average, about 19 percent lower bonus payments compared to 2008. The economic rebound, then, leads to an average increase in bonus payments to even above pre-crisis level. In 2011, average bonus payments exceed the pre-crisis bonuses of 2008 by 15 percent. The results of fixed salaries also confirm the cross section analysis of Figure 2 above and show slight increases. This leads to a median increase of total compensation from 2008 to 2011 of about 9 percent.

Figure 3 about here

Employees also considerably differ in terms of compensation changes with respect to precrisis levels. Figure 4 shows the distribution of indexed compensation components 20082011. We find huge differences with respect to bonus payments. In 2011, the majority of employees gained in terms of bonus payments relative to pre-crisis payments. About 30 percent of managers suffered in terms of reductions in real bonus payments, though. Fixed salary changes are much more homogeneous over the period of crisis. Only 9 percent of the employees had to face losses in fixed salaries from 2008 to 2011. For the better part of the chemical management, the economic upturn compensated for losses during the crisis. Only 17 percent of the managers suffered in terms of reductions in real total compensation.

Figure 4 about here

To sum up: our descriptive findings confirm previous results on the development of bonus payments during the economic crisis (see e.g. Kampkötter and Sliwka, 2011). Since bonus payments decline in times of crisis and increase in times of economic recovery on average, those findings are also in line with our Hypotheses 1a) and 1b) of Section 3. Negative serial correlation of bonus payments reveals that power considerations appear to be of minor importance. The low amount of changes in fixed salaries over time confirms wage rigidity considerations. 


\subsection{Determinants of changes in compensation}

Based on the descriptive overview, we want to examine in more detail whether there are certain groups of winners and losers of the economic crisis. We therefore run median regressions on the indexed annual compensation components $(2008=100)$. Table 2 shows the influence of the individual and firm characteristics on bonus payments of the years 2009, 2010 and 2011 relative to the reference year 2008. The corresponding results for fixed salaries and total compensation are reported in Tables 3 and 4. We prefer median regressions over OLS models because the median is more robust with regard to outliers in the sample.

Individual and firm characteristics act as independent variables. The most important firm and job characteristics in our empirical analysis are tenure (in years), hierarchy level, firm size, functional area and branch. Jobs at a particular hierarchical position may vary between different firms with regard to their firm size. Regarding firm size, we distinguish between three categories related to the numbers of firms`employees. We also control for nine functional areas and fourteen lines of business. The individual characteristics include age, sex and schooling degrees. We further include the field of study at university and whether a manager was promoted to a higher hierarchical level. We also control for firm changes. Information with regard to the operationalization of these items can be found in Table A of the appendix.

Results of Table 2 show no significant relationship between the hierarchical level and increases in bonus payments for the years 2009, 2010 and 2011 relative to the reference year 2008. Although coefficients for level 2 are positive, we do not find direct evidence for our Hypothesis 2, which states that decreases in bonus payments during the crisis and increases in the upturn are particularly relevant for managers in higher hierarchical positions. However, the results of Table 3 reveal differences between changes in fixed salaries with respect to the hierarchical level. Managers at level 2 gain more on average in terms of fixed salary changes relative to their lower level peers. This is particularly true for the economic upturn (2011). Power considerations as described above may be one possible explanation for this pattern. We also get positive coefficients for high level managers with respect to total compensation (see Table 4), since fixed salaries account for the major part of it. Level 2 manager denote significant higher increases in total compensation in 2010 and 2011 compared to 2008. This result is partly driven by particular increases with regard to other compensation components, such as stock options, which are not in the focus of this paper. Further analysis on the data shows that managers of level 2 particularly benefit from the exercising of stock options in 2011. 
Bonus payments are more relevant in large firms. In line with our Hypothesis 3, small firms employees suffer less during the economic downturn (2010) with higher bonus payments relative to large firms`employees (see Table 2). We do not find significant differences in bonus payments of 2011 between the highest and lower firm size categories. Note again that we focus on relative bonus changes from 2008 to 2011. Table B of the appendix shows the relation of the firm size on bonus payments of the year 2011 relative to the reference year 2010. It turns out that especially employees in large firms gain from the economic upturn (2011) with respect to bonus payments, which also confirms our Hypothesis 3 on the effect of firm size on bonus changes. As expected, decreases in bonus payments during the crisis and increases in the upturn are particularly relevant for managers in large firms. There is also a clear link between firm size and changes in fixed salary payments (see Table 3). Small firms`employees denote significant lower fixed salary increases over time. The qualitative results are similar to the findings of Babecky et al. (2010), who indicate that firm size is positively related with downward wage rigidity. Since we find somewhat opposing trends in the development of fixed and variable payments, changes in total payments are attached to the firm size to a remarkable but mixed degree. Managers of mediums-sized firms are better off in 2010 because of advantages in bonus development. However, employees in large firms benefit in terms of total compensation changes in 2011

Concerning the other independent variables, the results of Tables 2 to 4 show that older employees are affected by the economic crisis in particular. In 2011, the more senior managers are worse off in terms of fixed and total compensation changes compared to young employees. Employees with long firm tenure receive smaller bonus increases in 2011, on average. The empirical results are in line with the human capital considerations mentioned in section 3. Power considerations seem to play a minor role in terms of compensation changes with respect to employees`age. Interpretations may also include the aspect that many of the elderly still have traditional contracts with high fixed salaries and less bonus relevance. Then, many firms may use bonus payments to align age differences in compensation.

In line with our considerations of section 3, findings indicate that managers who changed their job suffer in terms of bonus payments in the short run. They gain in terms of fixed salary changes in 2010, though (see Table 3). 
Table 2 to 4

about here

We can assign managers to certain firms in a majority of cases. It is likely that firm effects can be an important factor in determining compensation changes. In order to check the robustness of our results, we re-estimate the regressions of Tables 2 to 4 with the managers of the 50 firms with most observations. By doing this, we reduce the sample size to 771 individuals. We run OLS regression and use robust standard errors, clustered at the firm level (see Table $\mathrm{C}$ in the appendix). In order to control for firm effects, we include firm dummies instead of dummies for firm size. The general results do not change.

In correspondence with the variation in bonus payments for certain management groups, it is interesting to note that inequality in total compensation among the whole group of managers in the sector measured with the Gini index decreased during the crisis (see Table D in the appendix). This process of compensation compression is driven by bonus payments. The dispersion of fixed salaries is quite constant over time. The economic upturn in 2011 again leads to an increase in income inequality, to even above pre-crisis level. That is partly because of increased inequality of bonus payments, but also - as we already mentioned above - due to the effect that several well paid managers exerted stock options in 2011.

\section{Conclusion}

This paper contains analyses of a unique balanced panel of highly qualified professionals and middle management employees of the German chemical industry. Based on theoretical considerations, we provide an extensive overview on the incidence and determinants of compensation reductions during the crisis and subsequent increases in the economic recovery for the German chemical management. To the best of our knowledge, this issue has been addressed only insufficiently before.

Our longitudinal analysis of the whole observation period has provided support for most of our hypotheses. We find that, on average, bonus payments considerably decrease during the crisis. The economic upturn then leads to an average increase in variable payments to even above the pre-crisis level. Compared to the high extent of variation in bonuses, we show that fixed salaries are much more stable over the period of crisis. There are huge differences 
across employees with respect to the development of bonus payments. Changes in fixed salaries and total compensation are much more homogeneous over the period of crisis. For the better part of the chemical management, the economic upturn compensates for losses during the crisis. Hence, on average, compensation reductions in times of crisis do not lead to longterm earning losses among employees.

We refer to certain groups of managers in particular by taking some determinants of compensation changes into account. Looking at economic relevance, we find that employees' age, firm size and hierarchical level affect compensation changes most during and subsequent to the economic crisis. Employees who change their job suffer in terms of bonus payments. They gain in terms of fixed salaries, though. Controlling for unobserved firm heterogeneity generally leads to the same results.

We find that, in general, the share of profiting from the economic upturn is higher for the group of managers who suffered during the crisis than that of those managers who profited with respect to bonus payments. In consequence, our findings hint at the relevance of an incentive perspective. However, we also examine that in particular managers on higher levels of the hierarchy seem to have more power to influence their compensation than others.

Assuming that bonus payments at least partly depend on the performance of the individuals in most cases, some limitations of our study stem from the data. For examples we do not have information on the outcome of firms performance-appraisal systems. Facing the explanatory power of our multivariate models in section 5 , there are several other factors that determine bonus changes across individuals and firms. In this study, we focus on the individual perspective. Further research may be extended to the firm perspective by including company performance information. More detailed information on firms' bonus policies and business strategies could also be useful. Since the economic crisis has caused companies to reduce costs, firms may considerably differ in the manner in which they react to the crisis. Adjusting payments can be an appropriate measure of the firms to reduce costs and to cope with a crisis. Large firms could make use of the bonus flexibility in particular, which makes compensation more volatile (Milkovich and Newman, 1996). An alternative strategy of firms may also be an adjusting of the numbers of employees. The chosen strategy of a firm may depend on the possibilities rendered by the type of contracts signed with the employees and the extent to which financial and demand constraints trigger cost reduction (Westergard-Nielsen and Neamtu, 2012). Small firms might have more financial problems, which could lead to job cuts instead 
of using wage flexibility. In consequence, small firms' bonuses may vary to a smaller extent than those of large firms.

Differences in compensation changes may also be attributed to the way and extent firms have been affected by the crisis. They may have been affected, for instance, by decreasing demand for goods and services or by a credit crunch. Thus, large firms' managers might be less affected by the economic crisis because bigger firms probably have better access to bank loans (Westergard-Nielsen \& Neamtu, 2012). As a result, they have fewer credit problems or a better financial situation during the crisis, which leads to a smaller extent of compensation reductions for larger firms` managers. However, performances of firms may considerably differ as well as firms` internal incentive structures, so that employees of some firms are hit much harder than those of others.

Further research may also contribute to the issue of whether there are long-term effects for the certain groups of winners and losers of the economic crisis Future research effort is also needed to develop more precise tests of theoretical models, such as disentangling the relevance of the power and the incentive approaches. Therefore, more specific data are needed to generate better proxies for managerial power and incentives. 


\section{References}

Arrow, K. J. (1985). "The Economics of Agency", in Pratt, J.W. und Zeckhauser, R.J. Ed., Principals and Agents: The Structure of Business, Boston, pp. 37-51.

Babecky, J., Du Caju, P., Kosma, T., Lawless, M., Messina, J., \& Room, T. (2010). Downward Nominal and Real Wage Rigidity: Survey Evidence from European Firms. In: The Scandinavian Journal of Economics, Vol. 112 (4), pp. 884-910.

Baker, G. P., Gibbs, M., \& Holström, B. (1994). The wage policy of a firm. In: Quarterly Journal of Economics, pp. 921-955.

Bauer, T., Bonin, H., Goette, L., \& Sunde, U. (2007). Real and Nominal Wage Rigidities and the Rate of Inflation: Evidence from West and German Micro Data. In: The Economic Journal, Vol. 117 (524), pp. 508-529.

Bebchuk, L. A., Fried, J. M. (2003): Executive compensation as an agency problem. In: Journal of Economic Perspectives, Vol. 17, No. 3, pp. 71-92.

Becker, G. S. (1964). Human Capial: A Theoretical and Empirical Analysis With Special Reference to Education. Chicago: University of Chicago Press.

Berle, A. A., \& Means, G. C. (1932). The Modern Corporation and Private Property, New York: Harcourt, Brace \& World.

Bewley, T. F. (1999). Why Wages Don`t Fall During a Rescession. Cambridge, Mass.: Harvard Univ. Press.

Brenner, S., \& Schwalbach, J. (2003). Management quality, firm size and managerial compensation: A comparison between Germany and the UK. In: Schmalenbach Business Review, Vol. 55, pp. 280-293.

Brenke, K., Rinne, U., Zimmermann, K. F. (2011). Short-time Work: The German Answer to the Great Recession. IZA Discussion paper No. 5780. 
Card, D., \& Hyslop, D. (1997). Does Inflation Grease the Wheels of the Labor Market? In C. Romer, \& D. Romer, In: Reducing Inflation: Motivation and Strategy (pp. 71-113). Chicago University Press.

Core, J., Holthausen, R., Larcker, D. (1999): Corporate governance, chief executive officer compensation, and firm performance. In: The Journal of Financial Economics, Vol. 51, pp. 371-406.

Cyert, R., Sok-Hyon, K., Praveen, K. (2002): Corporate governance, takeovers, and topmanagement compensation: Theory and evidence. In: Management Science, Vol. 48, pp. 453-469.

Dohmen, T. J. (2004). Performance, Seniority, and Wages: Formal Salary Systems and Individual Earnings Profiles. In: Labour Economics, Vol. 11, No. 6, pp. 741-763.

Elston, J. A., Goldberg, L. G. (2003): Executive Compensation and Agency Costs in Germany. In: Journal of Banking \& Finance, Vol. 27, pp. 1391-1410.

Erkens, D., Hung, M., Matos, P. (2009). Corporate Governance in the 2007-2008 Financial Crisis: Evidence from the Financial Institutions Worldwide . University of Southern California Working Paper.

Fahlenbrach, R. (2009): Shareholder Rights, Boards and Executive Compensation. In: Review of Finance, Vol. 13, pp. 81-113.

Fahlenbrach, R., Stulz, R. M. (2011). Bank CEO Incentives and the credit crisis. In: Journal of Financial Economics, Vol. 99, pp. 11-26.

Fabbri, F., \& Marin, D. (2012). What explains the rise in CEO Pay in Germany? A Panel Data Analysis for 1977-2009. IZA Discussion paper No. 6420.

Fama, E., \& Jensen, M. C. (1983). Seperation of ownership and control. In: Journal of Law and Economics, Vol. 26, pp. 375-393.

Fehr, E., \& Falk, A. (1999). Wage Rigiditiy in a Competitive Incomplete Contract Market. In: Journal of Political Economy, Vol. 107, No. 1, pp. 106-134. 
Finkelstein, S., Hambrick, D. C. (1989): Chief executive compensation: A study of the interaction of markets and political processes. In: Strategic Management Journal, Vol. 10, pp. 121-134.

Garen, J. (1985), Worker heterogeneity, job screening, and firm-size, Journal of Political Economy, Vol. 93 No. 4, pp. 715-39.

Gregg, P., Jewell, S., \& Tonks, I. (2012). Executive Pay and Performance: Did Bankers` Bonuses Cause the Crisis? In: International Review of Finance, Vol. 12:1, pp. 89-122.

Goldberg, L. G., Idson, T. L. (1995): Executive compensation and agency effects. In: Financial Review, Vol. 301, pp. 313-335.

Grund, C., \& Kräkel, M. (2012). Bonus Payments, Hierachy Levels, And Tenure: Theoretical Considerations And Empirical Evidence. In: Schmalenbach Business Review, Vol. 64., pp. 102-124.

Jensen, M. C., \& Meckling, W. H. (1976). Theory of the Firm: Managerial Behavior, Agency Costs and Ownership Structure. In: Journal of Financial Economics 3, pp. 305-360.

Jensen, M. C., Murphy, K. J. (1990): Performance pay and top-management incentives. In: Journal of Political Economy, Vol. 98, No. 2, pp. 225-264.

Kampkötter, P., \& Sliwka, D. (2011). Die Wirkung der Finanzkrise auf Bonuszahlungen in deutschen Banken und Finanzdienstleisungsinstitutionen. In: Die Unternehmung. Swiss Journal of Business Research and Practice, Vol. 65., Sonderedition 1, pp. 151164.

Kräkel, M., \& Schöttner, A. (2012). Internal labor markets and worker rents. In: Journal of Economic Behavior \& Organization, Elsevier, Vol. 84 (2), pp. 491-509.

Lindbeck, A., \& Snower, D. J. (1989). The Insider-Outsider Theory of Employment and Unemployment. Cambridge, Mass.: MIT Press.

Milkovich, G. T., \& Newman, J. M. (1996). Compensation. Chicago: Irwin.

Mincer, J. (1974). Schooling, Experience, and Earnings. New York: Columbia University Press. 
Nash, D. (2003). Determinants of the use of financial incentives in investment banking. ESCR Center of Business Research Working paper No. 256.

Nastansky, A., \& Lanz, R. (2010). Bonuszahlungen in der Kreditwirtschaft: Analyse, Regulierung und Entwicklungstendenzen. Discussion paper No. 41, ISSN: 0949068X, Universität Potsdam.

O`Farrrell, R. (2010). Wages in the crisis. European Trade Union Institute (ETUI) Working Paper No. 2010.03.

Oi, W.Y. and Idson, T.L. (1999a), "Firm-size and wages", in Ashenfelter, O. and Card, D. (Eds), Handbook of Labor Economics, 3, North Holland, Amsterdam, pp. 2166-214.

Ortin-Angel, P., \& Salas-Fumas, V. (1998). Agency-Theory and Internal-Labor-Market Explanations of Bonus Payments: Emprical Evidence from Spanish Firms. In: Journal of Economics \& Management Strategy, Vol. 7, No. 4., pp. 573-613.

Rosen, Sherwin (1986). Prizes and Incentives in Elimination Tournaments. In: American Economic Review, Vol. 76, pp. 701-715.

Ross, S. A. (1973). "The Economics Theory of Agency: The Principal's Problem". In: American Economic Review, 63, pp. 134-139.

Shapiro, C., and Stiglitz, J. E. (1984), Equilibrium Unemployment as a Worker Discipline Device, In: American Economic Review 74, pp. 433-444.

Stiglitz, J. E. (1974), Alternative Theories of Wage Determination and Unemployment in LDC's: The Labor Turnover Model. In: Quarterly Journal of Economics, Vol. 88, pp. 194-227.

Stiglitz, J. E. (1986). Theories Of Wage Rigidity. In J. L. Butkiewicz, K. J. Koford, \& J. B. Miller, Keynes`Economic Legacy: Contemporary Economic Theories (pp. 153-206). New York: Praeger Publishers.

Westergard-Nielsen, N., \& Neamtu, I. (2012). How are firms affected by the crisis and how do they react? IZA Discussion paper No. 6671. 


\section{Tables and Figures}

Table 1: Descriptive Statistics

\begin{tabular}{|c|c|c|c|}
\hline Variable & $\mathbf{n}$ & Mean & $\begin{array}{c}\text { Standard- } \\
\text { deviation }\end{array}$ \\
\hline Total Compensation (real) & 5,464 & 120,515 & 42,744 \\
\hline \multicolumn{4}{|l|}{ Fixed Salaries variables (real) } \\
\hline Fixed salary $[€]$ & 5,464 & 95,085 & 21,804 \\
\hline Relative changes in fixed salary & 3,953 & 0.029 & 0.268 \\
\hline \multicolumn{4}{|l|}{ Bonus variables $($ real $)$} \\
\hline$\overline{\text { Bonus }[€]}$ & 5,464 & 19,246 & 15,240 \\
\hline Relative changes in bonus payments & 3,953 & 0.275 & 2.577 \\
\hline \multicolumn{4}{|l|}{ Demographics } \\
\hline Female (dummy, 1=yes) & 5,464 & 0.102 & 0.303 \\
\hline Age & 5,464 & 49.0 & 6,801 \\
\hline Tenure [years] & 5,464 & 18.2 & 38,78 \\
\hline Firm changes $[$ Tenure $\leq 1]$ & 5,464 & 0.013 & 0.114 \\
\hline \multicolumn{4}{|l|}{ Schooling } \\
\hline University degree & 4,840 & 0.885 & \\
\hline University of applied science degree & 527 & 0.096 & \\
\hline Apprenticeship degree & 97 & 0.017 & \\
\hline \multicolumn{4}{|l|}{ Firm size (number of employees) } \\
\hline$\leq 1,000$ employees & 772 & 0.141 & \\
\hline $1,000-10,000$ employees & 2,011 & 0.368 & \\
\hline$\geq 10,000$ employees & 2,681 & 0.491 & \\
\hline \multicolumn{4}{|l|}{ Hierarchical Level } \\
\hline Level 2 & 704 & 0.128 & \\
\hline Level 3 & 3,065 & 0.561 & \\
\hline Level 4 & 1,695 & 0.310 & \\
\hline \multicolumn{4}{|l|}{$\underline{J o b}$} \\
\hline Production & 1,060 & 0.193 & \\
\hline Research and development & 1,597 & 0.292 & \\
\hline Technology & 551 & 0.100 & \\
\hline Applications engineering & 376 & 0.068 & \\
\hline Sales, marketing, logistics, sourcing & 581 & 0.106 & \\
\hline Finance, controlling, human resources & 311 & 0.056 & \\
\hline Technical supervision & 369 & 0.067 & \\
\hline IT & 126 & 0.023 & \\
\hline Other & 493 & 0.090 & \\
\hline \multicolumn{4}{|l|}{ Field of study at university } \\
\hline Chemistry & 4,870 & 0.891 & \\
\hline Engineering & 358 & 0.065 & \\
\hline Business/economics & 209 & 0.038 & \\
\hline Other natural sciences/medicine & 27 & 0.005 & \\
\hline \multicolumn{4}{|l|}{ Industry } \\
\hline Basic chemicals & 388 & 0.071 & \\
\hline Synthetics & 534 & 0.097 & \\
\hline Paint and varnish/adhesive sealing materials & 375 & 0.068 & \\
\hline Mineral oil & 81 & 0.014 & \\
\hline Plant protection & 212 & 0.038 & \\
\hline Pharmacy & 1,131 & 0.207 & \\
\hline Specialty chemicals & 1,361 & 0.249 & \\
\hline Detergent/cosmetics & 169 & 0.031 & \\
\hline IT & 69 & 0.012 & \\
\hline Administration/attendance & 241 & 0.044 & \\
\hline Logistics & 20 & 0.004 & \\
\hline Engineering & 155 & 0.028 & \\
\hline Other chemical industry & 350 & 0.059 & \\
\hline Other branch of industry & 378 & 0.069 & \\
\hline Promotion (dummy,1=yes) & 5,464 & 0.047 & 0.212 \\
\hline \multicolumn{4}{|l|}{ Year } \\
\hline 2008 & 1,366 & 0.433 & \\
\hline 2009 & 1,366 & 0.433 & \\
\hline 2010 & 1,366 & 0.433 & \\
\hline 2011 & 1,366 & 0.433 & \\
\hline
\end{tabular}


Figure 1: Structure of compensation.

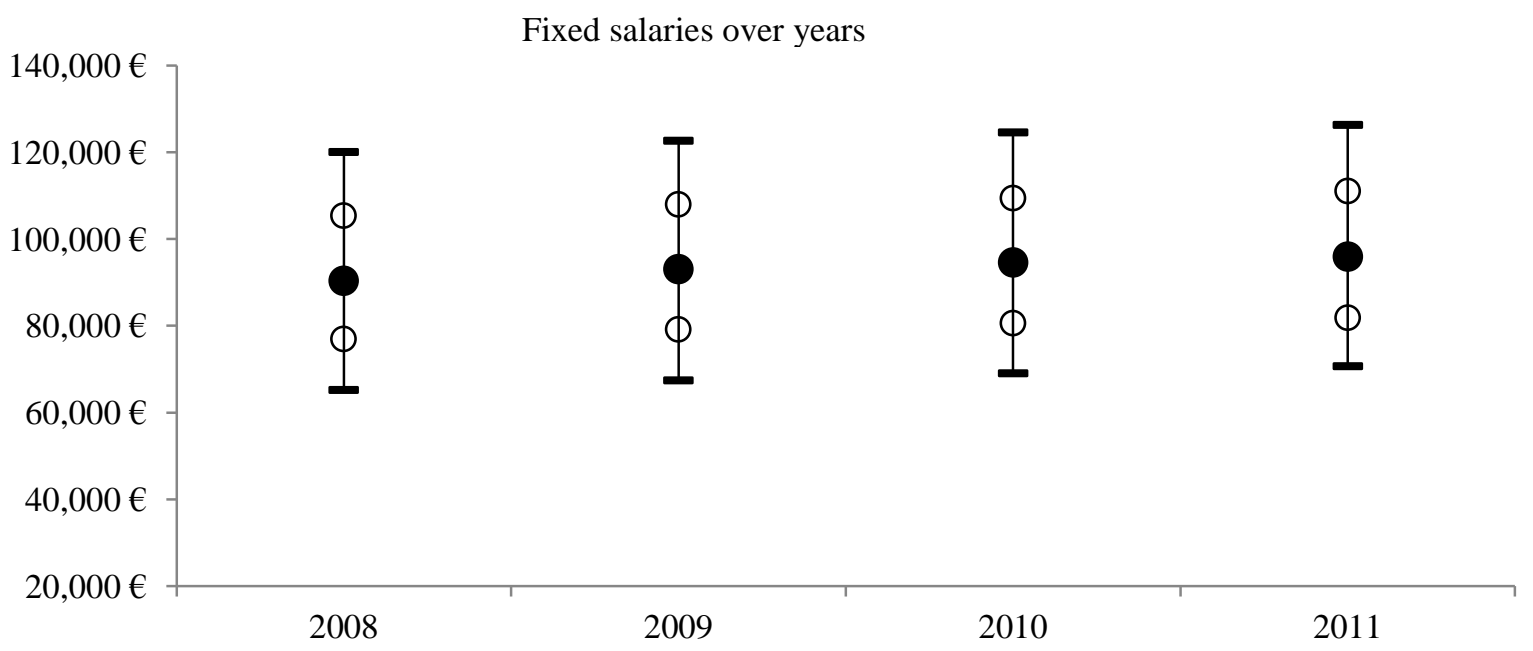

Bonus payments over years
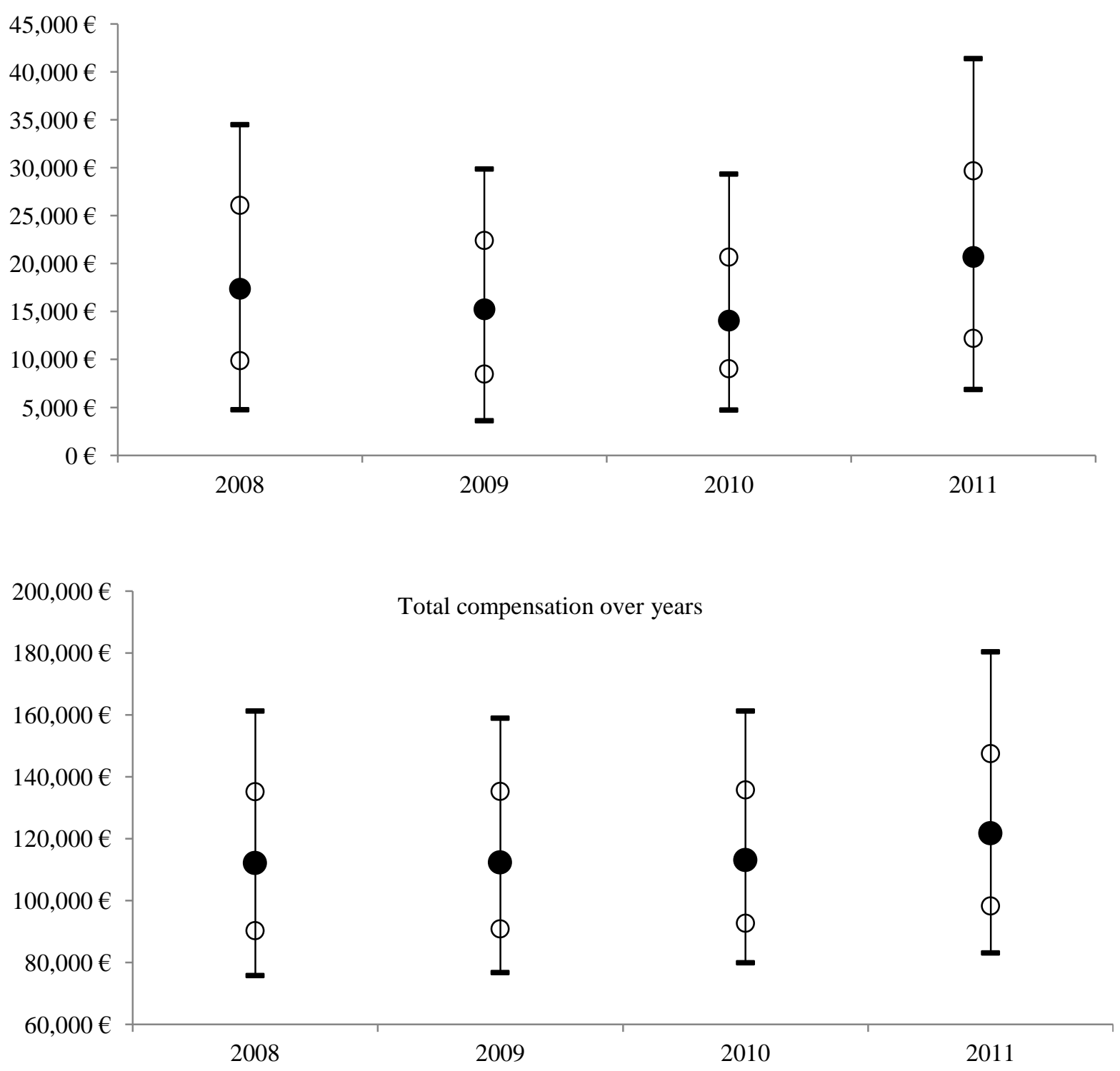

- median $\circ 25 / 75$ percentile - $10 / 90$ percentile 
Figure 2: Development of compensation over years.
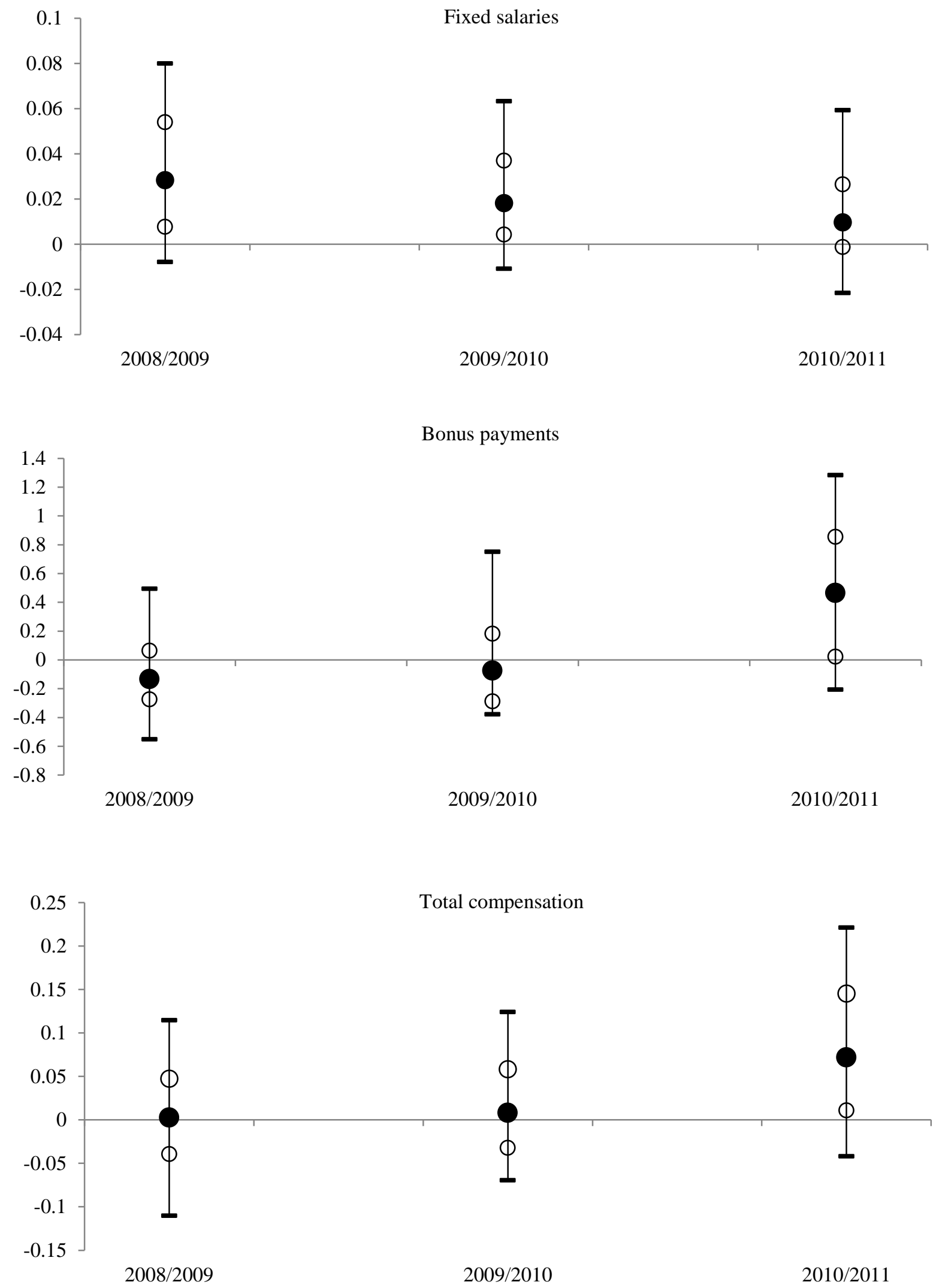

- median $\circ 25 / 75$ percentile - 10/90 percentile 
Figure 3: Compensation components relative to the year 2008.

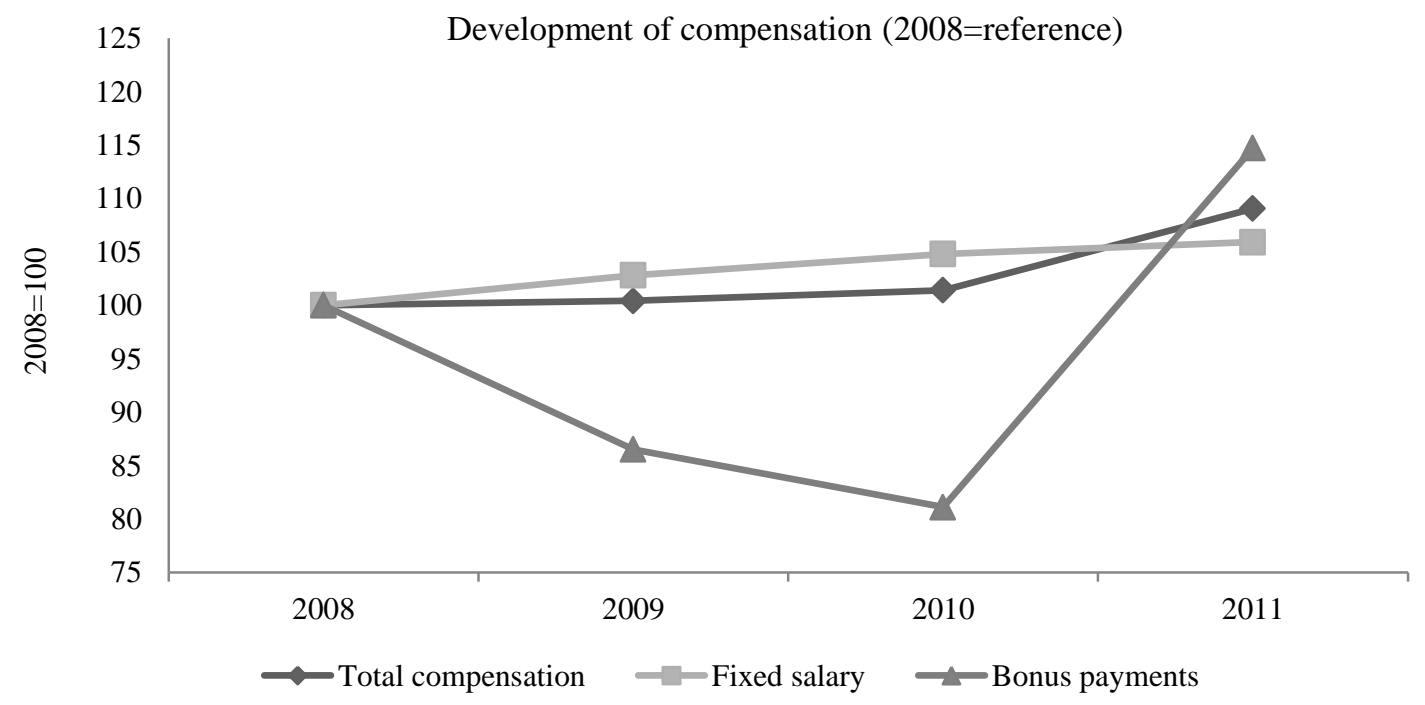

Figure 4: Distribution of indexed compensation components 2008-2011.

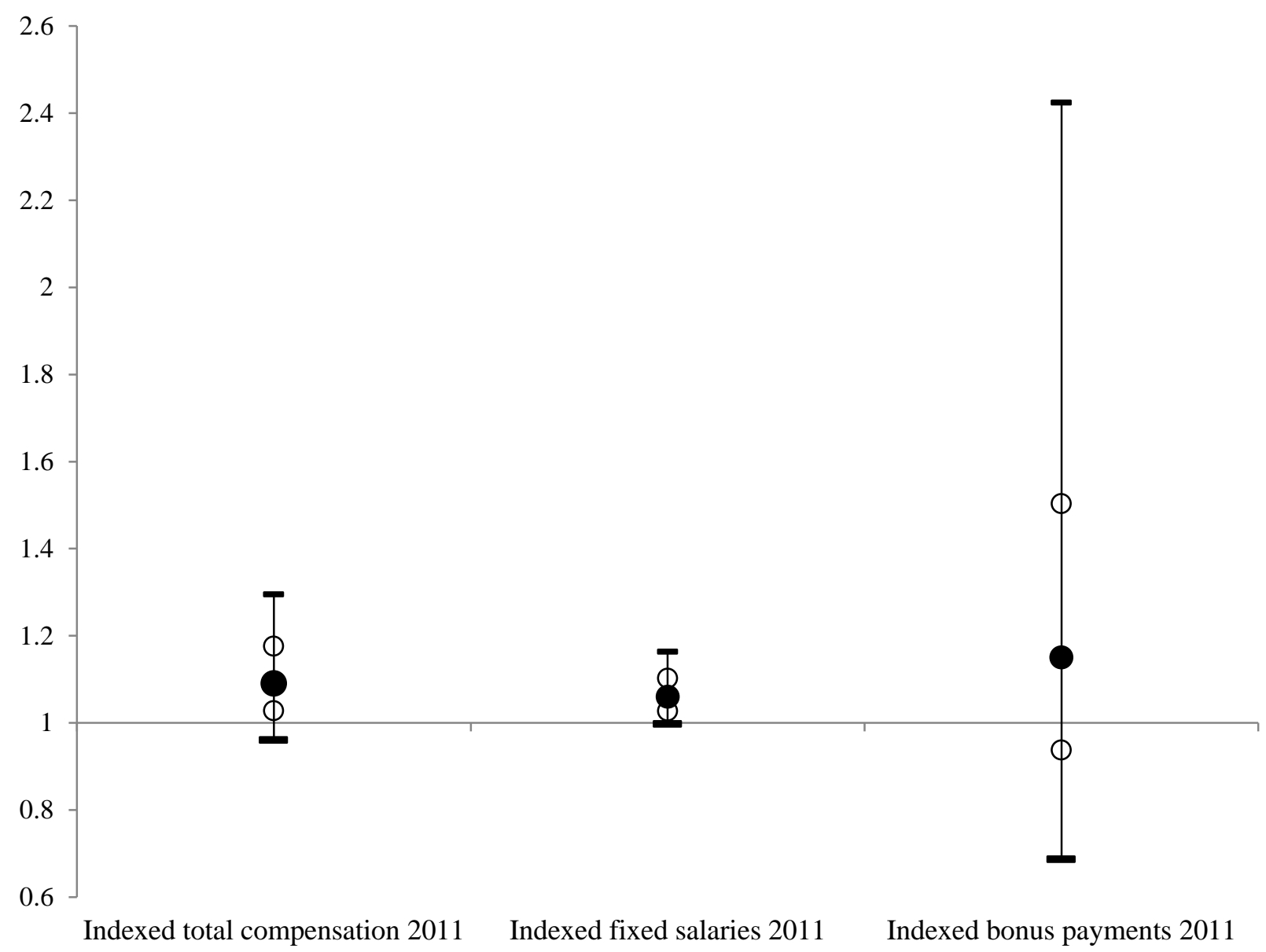

- median $\circ 25 / 75$ percentile $-10 / 90$ percentile 
Table 2: Median regression on indexed bonus payments

\begin{tabular}{|c|c|c|c|}
\hline \multirow{2}{*}{$\begin{array}{l}\text { Reference } 2008 \\
\text { Indexed compensation components }\end{array}$} & \multicolumn{3}{|c|}{$\begin{array}{c}\text { Indexed } \\
\underline{\text { Bonus payments }} \\
\end{array}$} \\
\hline & $\underline{2009}$ & $\underline{2010}$ & $\underline{2011}$ \\
\hline Age & $-0.118(0.291)$ & $-0.501 * * *(0.182)$ & $-0.403(0.346)$ \\
\hline Female (1=yes) & $-0.548(2.800)$ & $3.221(3.867)$ & $-4.054(5.175)$ \\
\hline Tenure & $-0.215(0.273)$ & $-0.002(0.009)$ & $-0.931 * * *(0.330)$ \\
\hline \multicolumn{4}{|l|}{ Schooling (base: university degree) } \\
\hline University of applied sciences degree & $-3.395(5.207)$ & $-3.169(8.560)$ & $4.231(10.51)$ \\
\hline Apprenticeship degree & $-6.134 *(6.859)$ & $1.609(7.341)$ & $14.48(10.34)$ \\
\hline \multicolumn{4}{|l|}{$\underline{\text { Firm size (base: } \geq 10,000 \text { employees) }}$} \\
\hline$\leq 1,000$ employees & $-2.870 *(4.844)$ & $17.93 * * *(5.004)$ & $-7.537(4.964)$ \\
\hline $1,000-10,000$ employees & $0.576(2.205)$ & $24.18 * * *(2.837)$ & $3.070(3.417)$ \\
\hline \multicolumn{4}{|l|}{ Level of hierarchy (base: level 4) } \\
\hline Level 2 & $2.298(3.724)$ & $5.845(5.117)$ & $2.478(5.361)$ \\
\hline Level 3 & $0.250(2.050)$ & $-3.162(2.840)$ & $0.210(3.411)$ \\
\hline \multicolumn{4}{|l|}{ Field of study (base: chemistry) } \\
\hline Engineering & $3.537(5.548)$ & $4.939(9.066)$ & $-0.848(10.59)$ \\
\hline Business/economics & $-4.201(5.525)$ & $-0.446(6.360)$ & $-6.348(7.936)$ \\
\hline Other natural science/medicine & $-12.87(12.77)$ & $-15.31(19.26)$ & $7.941(17.95)$ \\
\hline Promotion (1=yes) & $1.860(3.746)$ & $1.540(3.168)$ & $0.444(3.470)$ \\
\hline Firm change (1=yes) & $-5.821(10.58)$ & $-9.543(8.853)$ & $-37.95 * * *(12.09)$ \\
\hline Branch dummies & yes & yes & yes \\
\hline Job dummies & yes & yes & yes \\
\hline Intercept & $90.49 * * *(10.03)$ & $83.68 * * *(8.448)$ & $160.3 * * *(14.84)$ \\
\hline Numbers of observations & $1,322^{\mathrm{a}}$ & $1,322^{\mathrm{a}}$ & $1,322^{\mathrm{a}}$ \\
\hline Pseudo $R^{2}$ & 0.039 & 0.082 & 0.046 \\
\hline
\end{tabular}

Notes: The table reports coefficients and robust standard errors (in parentheses). Significant results at the $10 \%, 5 \%$ and $1 \%$ levels with ***; and *** respectively. a) 34 observations with zero bonus payments in 2008. 
Table 3: Median regression on indexed fixed salary

\begin{tabular}{|c|c|c|c|}
\hline \multirow{2}{*}{$\begin{array}{l}\text { Reference } 2008 \\
\text { Indexed compensation components }\end{array}$} & \multicolumn{3}{|c|}{$\begin{array}{c}\text { Indexed } \\
\text { Fixed salary }\end{array}$} \\
\hline & $\underline{2009}$ & $\underline{2010}$ & $\underline{2011}$ \\
\hline Age & $-0.064 * * *(0.023)$ & $-0.215 * * *(0.229)$ & $-0.332 * * *(0.045)$ \\
\hline Female (1=yes) & $-0.435(0.307)$ & $-0.556(0.525)$ & $-1.227 * *(0.612)$ \\
\hline Tenure & $-0.048 * *(0.020)$ & $0.003(0.001)$ & $-0.076 * *(0.033)$ \\
\hline \multicolumn{4}{|l|}{ Schooling (base: university degree) } \\
\hline University of applied sciences degree & $-0.509(0.554)$ & $-0.241(0.589)$ & $1.143(0.824)$ \\
\hline Apprenticeship degree & $0.736(1.054)$ & $0.104(0.912)$ & $2.236(2.237)$ \\
\hline \multicolumn{4}{|l|}{ Firm size (base: $\geq 10,000$ employees) } \\
\hline$\leq 1,000$ employees & $-1.762 * * *(0.333)$ & $-2.642 * * *(0.394)$ & $-3.118 * * *(0.539)$ \\
\hline $1,000-10,000$ employees & $-1.110 * * *(0.210)$ & $-1.632 * * *(0.314)$ & $-1.610 * * *(0.366)$ \\
\hline \multicolumn{4}{|l|}{ Level of hierarchy (base: level 4) } \\
\hline Level 2 & $0.772 *(0.430)$ & $0.698(0.607)$ & $2.465 * * *(0.828)$ \\
\hline Level 3 & $0.500 * *(0.193)$ & $0.222(0.321)$ & $1.288 * * *(0.412)$ \\
\hline \multicolumn{4}{|l|}{ Field of study (base: chemistry) } \\
\hline Engineering & $0.407(0.654)$ & $0.011(0.661)$ & $-0.891(1.054)$ \\
\hline Business/economics & $-0.052(0.665)$ & $0.488(0.648)$ & $-0.232(1.418)$ \\
\hline Other natural science/medicine & $1.843(1.175)$ & $-0.318(1.382)$ & $0.216(2.460)$ \\
\hline Promotion (1=yes) & $-0.288(0.522)$ & $0.338(0.410)$ & $0.047(0.447)$ \\
\hline Firm change (1=yes) & $0.828(3.759)$ & $2.656^{* * *}(0.907)$ & $2.381(1.484)$ \\
\hline Branch dummies & yes & yes & yes \\
\hline Job dummies & yes & yes & yes \\
\hline Intercept & $106.9 * * *(0.9304)$ & $116.5^{* * *}(1.1448)$ & $125.3^{* * * *}(1.962)$ \\
\hline Numbers of observations & 1,366 & 1,366 & 1,366 \\
\hline Pseudo $\mathrm{R}^{2}$ & 0.057 & 0.098 & 0.129 \\
\hline
\end{tabular}

Notes: The table reports coefficients and robust standard errors (in parentheses). Significant results at the $10 \%, 5 \%$ and $1 \%$ levels with $* * *$; and $* * *$ respectively. 
Table 4: Median regression on indexed total compensation

\begin{tabular}{|c|c|c|c|}
\hline \multirow{2}{*}{$\begin{array}{l}\text { Reference } 2008 \\
\text { Indexed compensation components }\end{array}$} & \multicolumn{3}{|c|}{$\begin{array}{c}\underline{\text { Indexed }} \\
\text { Total compensation } \\
\end{array}$} \\
\hline & $\underline{2009}$ & $\underline{2010}$ & $\underline{2011}$ \\
\hline Age & $-0.078(0.585)$ & $-0.309 * * *(0.047)$ & $-0.392 * * *(0.876)$ \\
\hline Female (1=yes) & $-0.082(0.767)$ & $0.829(0.880)$ & $-1.244(1.647)$ \\
\hline Tenure & $-0.110 * *(0.055)$ & $0.004 * * *(0.001)$ & $-0.199 * *(0.773)$ \\
\hline \multicolumn{4}{|l|}{ Schooling (base: university degree) } \\
\hline University of applied sciences degree & $-0.816(1.197)$ & $-2.199(1.464)$ & $-0.2433(1.595)$ \\
\hline Apprenticeship degree & $-2.130(1.517)$ & $-2.154(1.727)$ & $-2.307(4.221)$ \\
\hline \multicolumn{4}{|l|}{ Firm size (base: $\geq 10,000$ employees) } \\
\hline$\leq 1,000$ employees & $-2.475 * * *(0.934)$ & $1.300(1.034)$ & $-5.358 * * *(1.003)$ \\
\hline $1,000-10,000$ employees & $-0.524(0.513)$ & $3.178 * * *(0.627)$ & $-1.914 * *(0.790)$ \\
\hline \multicolumn{4}{|l|}{ Level of hierarchy (base: level 4) } \\
\hline Level 2 & $1.481(1.316)$ & $4.001 * * *(1.346)$ & $4.418 * * *(1.405)$ \\
\hline Level 3 & $-0.063(0.501)$ & $-0.859(0.655)$ & $2.316 * * *(0.769)$ \\
\hline \multicolumn{4}{|l|}{ Field of study (base: chemistry) } \\
\hline Engineering & $1.053(1.372)$ & $2.106(1.472)$ & $1.274(0.983)$ \\
\hline Business/economics & $-1.141(1.252)$ & $-0.017(1.428)$ & $1.371(2.092)$ \\
\hline Other natural science/medicine & $-1.895(2.082)$ & $0.735(3.004)$ & $-1.700(3.279)$ \\
\hline Promotion (1=yes) & $0.954(1.374)$ & $0.965(0.773)$ & $0.778(0.992)$ \\
\hline Firm change (1=yes) & $-0.898(5.089)$ & $-0.281(2.389)$ & $-3.463(2.099)$ \\
\hline Branch dummies & yes & yes & yes \\
\hline Job dummies & yes & yes & yes \\
\hline Intercept & $104.6^{* * *}(2.185)$ & $111.8 * * *(2.444)$ & $135.1 * * *(3.368)$ \\
\hline Numbers of observations & 1,366 & 1,366 & 1,366 \\
\hline Pseudo $\mathrm{R}^{2}$ & 0.064 & 0.082 & 0.091 \\
\hline
\end{tabular}

Notes: The table reports coefficients and robust standard errors (in parentheses). Significant results at the $10 \%, 5 \%$ and $1 \%$ levels with $* * *$; and $* * *$ respectively. 


\section{Appendix}

Figure A: Proportion of eligible managers without bonus (zero bonus payments).

proportion of managers without bonus

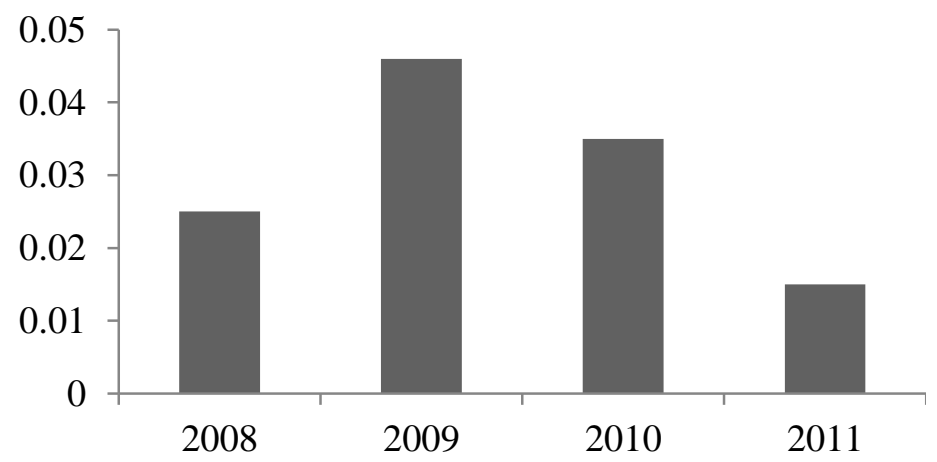

Table A: Variable definitions and operationalizations

\begin{tabular}{|c|c|}
\hline Total compensation & $\begin{array}{l}\text { Gross annual total monetary compensation. Computed as the sum of fixed } \\
\text { salaries, bonus payments and other income components (such as exercising } \\
\text { stock options, inventors' gratuities or jubilee payments) }\end{array}$ \\
\hline Fixed salaries & Gross annual fixed salaries, guaranteed by the work contract. \\
\hline Bonus payments & Gross annual bonus payments in euro. \\
\hline Relative bonus changes & Compute as the quotient of [(Bonus in $(\mathrm{t}) /$ Bonus in $(\mathrm{t}-1))-1] \times 100$. \\
\hline Fixed salary changes & $\begin{array}{l}\text { Compute as the quotient of [(Fixed salary in }(\mathrm{t}) / \text { Fixed salary in }(\mathrm{t}-1))-1] \mathrm{x} \\
100 .\end{array}$ \\
\hline Female & Dummy for females (1=yes) \\
\hline Tenure & Tenure with the firm in years \\
\hline Age & Current age of the worker (in years) \\
\hline Firm size & $\begin{array}{l}\text { Dummies for the size of the actual firm in which the manager is occupied. } \\
\text { As a proxy, the number of employees of the firm is used. There are } 3 \text { differ- } \\
\text { ent categories: (1) Up to } 100 \text { employees, (2) } 1001-10,000 \text { employees, ( } 3 \text { ) } \\
\text { more than } 10,000 \text { employees }\end{array}$ \\
\hline Hierarchical Level & $\begin{array}{l}\text { Dummies for the hierarchical level on which the managers works. In the } \\
\text { questionnaire, respondents are asked to allocate themselves to one of four } \\
\text { management levels, whereas level } 1 \text { represents the top-management level }\end{array}$ \\
\hline Field of study at university & $\begin{array}{l}\text { Dummies for the field of study. There are } 3 \text { different categories: (1) Chem- } \\
\text { istry, (2) Engineering, (3) Business/economics, (4) Other natural sci- } \\
\text { ence/economics. }\end{array}$ \\
\hline
\end{tabular}




\begin{tabular}{|l|l|}
\hline \multirow{2}{*}{ Industry } & $\begin{array}{l}\text { Dummies for the industry of the firm. There are dummies 14 for different } \\
\text { categories. (1) Basic chemicals, (2) Synthetics, (3) Paint \& varnish/adhesive } \\
\text { sealing materials, (4) Mineral oil, (5) Plant protection, (6) Pharmacy, (7) } \\
\text { Specialty chemicals, (8) Detergent/cosmetics, (9) IT, (10) Administra- } \\
\text { tion/attendance, (11) Logistics, (12) Engineering, (13) Other chemical in- } \\
\text { dustry, (14) other branch of industry. }\end{array}$ \\
\hline Functional area & $\begin{array}{l}\text { Dummies for the industry of the firm. There are dummies for 9 different } \\
\text { categories. (1) Production, (2) R\&D, (3) Technology, (4) Application engi- } \\
\text { neering, (5) Sales, marketing, logistics, sourcing (6) Finance, controlling, } \\
\text { HR (7) Technical supervision, (8) IT, (9) other. }\end{array}$ \\
\hline Year & Dummies for the observation year \\
\hline Schooling & $\begin{array}{l}\text { Dummies for the schooling qualification. (1) University degree, (2) Univer- } \\
\text { sity of applied sciences degree and (3) Apprenticeship degree. }\end{array}$ \\
\hline Promotion & Dummy for level changes of level 4 to 3 or level 3 to 2. (1=yes) \\
\hline Firm change & $\begin{array}{l}\text { Dummy for firm changes (1=yes). As a proxy, the years of tenure is used. } \\
\text { Firm change is a proxy for tenure } \leq 1 .\end{array}$ \\
\hline
\end{tabular}


Table B: Median regression on indexed total compensation from 2010 to $2011(2010=100)$

\begin{tabular}{|c|c|c|c|}
\hline Reference 2010 & $\begin{array}{c}\underline{\text { Indexed }} \\
\underline{\text { Bonus payments }} \\
\end{array}$ & $\begin{array}{l}\text { Indexed } \\
\text { Fixed salary }\end{array}$ & $\begin{array}{l}\text { Indexed } \\
\text { Total compensation }\end{array}$ \\
\hline Indexed compensation components & $\underline{2011}$ & $\underline{2011}$ & $\underline{2011}$ \\
\hline Age & $-1.158 * * *(0.3647)$ & $-0.1237 * * *(0.017)$ & $-0.321 * * *(0.074)$ \\
\hline Female (1=yes) & $-6.775(4.349)$ & $-0.6141 * *(0.237)$ & $-1.491(1.056)$ \\
\hline Tenure & $0.258(0.291)$ & $0.0024(0.012)$ & $0.094(0.064)$ \\
\hline \multicolumn{4}{|l|}{ Schooling (base: university degree) } \\
\hline University of applied sciences degree & $7.841(9.426)$ & $0.019(0.344)$ & $-0.509(1.241)$ \\
\hline Apprenticeship degree & $-10.55(13.86)$ & $0.372(0.692)$ & $-3.696^{*}(1.679)$ \\
\hline \multicolumn{4}{|l|}{ Firm size (base: $\geq 10,000$ employees) } \\
\hline$\leq 1,000$ employees & $-30.88 * * *(7.532)$ & $-0.304(0.238)$ & $-5.419 * * *(0.919)$ \\
\hline $1,000-10,000$ employees & $-29.21 * * *(3.482)$ & $-0.344(0.146)$ & $-5.876 * * *(0.647)$ \\
\hline \multicolumn{4}{|l|}{ Level of hierarchy (base: level 4) } \\
\hline Level 2 & $1.725(6.019)$ & $0.515 *(0.263)$ & $2.437 * *(1.147)$ \\
\hline Level 3 & $5.370(3.644)$ & $0.313 *(0.160)$ & $1.923 * * *(0.605)$ \\
\hline \multicolumn{4}{|l|}{ Field of study (base: chemistry) } \\
\hline Engineering & $-3.495(11.16)$ & $0.022(0.405)$ & $-0.461(1.829)$ \\
\hline Business/economics & $5.831(13.29)$ & $-0.017(0.543)$ & $1.471(1.642)$ \\
\hline Other natural science/medicine & $-14.32(11.04)$ & $0.895(0.911)$ & $-0.874(2.030)$ \\
\hline Promotion (1=yes) & $7.593(7.012)$ & $0.141(0.454)$ & $-0.496(1.309)$ \\
\hline Firm change (1=yes) & $-12.20(21.38)$ & $8.383 * * *(2.989)$ & $-0.586(6.8679$ \\
\hline Branch dummies & yes & Yes & yes \\
\hline Job dummies & yes & Yes & yes \\
\hline Intercept & $235.6 * * *(14.80)$ & $107.7 * * *(0.758)$ & $126.9 * * *(3.053)$ \\
\hline Numbers of observations & $1,318^{\mathrm{a}}$ & 1,366 & $1,1,366$ \\
\hline Pseudo $\mathrm{R}^{2}$ & 0.007 & 0.001 & 0.041 \\
\hline
\end{tabular}

Notes: The table reports coefficients and robust standard errors (in parentheses). Significant results at the 10\%, 5\% and $1 \%$ levels with $* * *$; and $* * *$ respectively. a) 48 observations with zero bonus payments in 2010. 
Table C: OLS regressions on indexed compensation components with firm clusters

\begin{tabular}{|c|c|c|c|c|c|c|c|c|c|}
\hline \multirow{2}{*}{$\begin{array}{l}\text { Reference } 2008 \\
\text { Indexed compensation components }\end{array}$} & \multicolumn{3}{|c|}{$\begin{array}{c}\underline{\text { Indexed }} \\
\text { Total compensation } \\
\end{array}$} & \multicolumn{3}{|c|}{$\begin{array}{c}\text { Indexed } \\
\text { Fixed salary } \\
\end{array}$} & \multicolumn{3}{|c|}{$\begin{array}{c}\underline{\text { Indexed }} \\
\text { Bonus payments }\end{array}$} \\
\hline & $\underline{2009}$ & $\underline{2010}$ & $\underline{2011}$ & $\underline{2009}$ & $\underline{2010}$ & $\underline{2011}$ & $\underline{2009}$ & $\underline{2010}$ & $\underline{2011}$ \\
\hline Age & $-0.254 * *$ & $-0.408 * * *$ & $-0.342 *$ & -0.027 & $-0.157 *$ & $-0.289 * * *$ & -1.168 & -1.621 & $-2.877 * *$ \\
\hline Female (1=yes) & -0.712 & 0.009 & -0.508 & -0.026 & 0.360 & 0.426 & 0.788 & -2.114 & 6.645 \\
\hline Tenure & -0.006 & -0.007 & -0.207 & -0.094 & $-0.108^{*}$ & $-0.147 *$ & -0.948 & -0.479 & -1.012 \\
\hline \multicolumn{10}{|l|}{ Schooling (base: university degree) } \\
\hline University of applied sciences degree & -0.392 & -1.135 & 0.681 & -2.080 & -0.267 & -0.516 & 9.339 & 4.503 & 23.85 \\
\hline Apprenticeship degree & -1.138 & -5.510 & -4.252 & -1.047 & 0.916 & 1.116 & -8.150 & -8.115 & 7.906 \\
\hline \multicolumn{10}{|l|}{ Level of hierarchy (base: level 4) } \\
\hline Level 2 & -3.135 & 7.685 & $13.02 *$ & 1.345 & $3.520^{*}$ & $3.277^{*}$ & -9.481 & 21.774 & 21.98 \\
\hline Level 3 & 0.269 & 0.602 & 1.757 & 0.194 & 0.651 & 0.348 & -13.75 & -5.112 & -8.889 \\
\hline \multicolumn{10}{|l|}{ Field of study (base: chemistry) } \\
\hline Engineering & -0.067 & 0.496 & 3.150 & 1.159 & -0.805 & -0.085 & -11.195 & 1.435 & 0.358 \\
\hline Business/economics & 0.544 & 6.943 & $7.006^{*}$ & -0.743 & -0.320 & 0.583 & 5.981 & 0.123 & 8.245 \\
\hline Other natural science/medicine & 1.956 & -5.638 & -5.758 & 3.039 & -1.618 & -0.406 & -10.64 & 13.134 & 16.38 \\
\hline Promotion (1=yes) & -0.111 & -0.907 & 1.148 & -0.254 & -0.306 & 1.325 & -10.68 & -8.674 & -1.984 \\
\hline Firm change (1=yes) & 6.348 & 1.432 & 3.416 & $6.266 * *$ & $4.468 *$ & 4.019 & -70.51 & $-46.07 * *$ & -27.84 \\
\hline Branch dummies & yes & yes & yes & yes & yes & yes & yes & yes & yes \\
\hline Job dummies & yes & yes & yes & yes & yes & yes & yes & yes & yes \\
\hline Intercept & $109.7 * * *$ & $117.8 * * *$ & $128.9 * * *$ & $106.1 * * *$ & $114.6^{* * *}$ & $124.3 * * *$ & $160.9 * * *$ & 171.41 & $292.9 * * *$ \\
\hline Numbers of observations & 771 & 771 & 771 & 771 & 771 & 771 & $762^{\mathrm{a})}$ & $762^{\text {a) }}$ & $762^{\text {a) }}$ \\
\hline Pseudo $\mathrm{R}^{2}$ & 0.192 & 0.241 & 0.323 & 0.176 & 0.192 & 0.257 & 0.045 & 0.186 & 0.312 \\
\hline
\end{tabular}

Notes: The table reports coefficients. Standard errors are robust and clustered at the firm level (50 firm clusters). We include dummies for the seven largest firms instead of firm size, not reported

here. Significant results at the $10 \%, 5 \%$ and $1 \%$ levels with ***; and *** respectively. a) 9 observations with zero bonus payments in 2008 . 
Table D: Gini coefficients of the components of compensation for each year.

\begin{tabular}{|l|c|c|c|}
\hline & Bonus & Fixed salary & Total compensation \\
\hline $\mathbf{2 0 0 8}$ & 0.369 & 0.129 & 0.173 \\
$\mathbf{2 0 0 9}$ & 0.349 & 0.128 & 0.163 \\
$\mathbf{2 0 1 0}$ & 0.344 & 0.127 & 0.171 \\
$\mathbf{2 0 1 1}$ & 0.357 & 0.124 & $0.182^{\mathrm{a}}$ \\
\hline
\end{tabular}

Notes: ${ }^{\mathrm{a}}$ The high inequality of total compensation in 2011 compared to 2008 is partly driven by the relevance of stocks and stock options. 